\title{
Air temperatures and occupational injuries in the construction industries: a report from Northern Italy (2000-2013)
}

\author{
Matteo RICCÒ ${ }^{1,2}$, Luigi VEZZOSI ${ }^{3}$, Federica BALZARINI ${ }^{4}$, \\ Anna ODONE ${ }^{4,5}$ and Carlo SIGNORELLI ${ }^{4}$ \\ ${ }^{1}$ AUSL-IRCCS di Reggio Emilia, Italy \\ ${ }^{2}$ Department of Prevention, Provincial Agency for Health Services (APSS) of \\ the Autonomous Province of Trento, Italy \\ ${ }^{3}$ Prevention of Infectious Disease Unit, Health Protection Agency Val Padana, Italy \\ ${ }^{4}$ School of Medicine, Vita-Salute San Raffaele University, Italy \\ ${ }^{5}$ Clinical Epidemiology and HTA Unit, IRCCS San Raffaele Scientific Institute, Italy
}

Received December 28, 2018 and accepted September 18, 2019

Published online in J-STAGE September 21, 2019

\begin{abstract}
The aim of this study was to assess the relationship between environmental temperatures and occupational injuries (OIs) in construction workers (CWs) from a subalpine region of NorthEastern Italy. Data about OIs from 2000 to 2013, and daily weather for the specific site of the events were retrieved. Risk for daily OIs was calculate through a Poisson regression model. Estimated daily incidence for OIs was 5.7 (95\%CI 5.5-5.8), or 2.8 OIs/10,000 workers/d (95\%CI 2.7-2.9), with higher rates for time periods characterized by high temperatures (daily maximum $\geq 35^{\circ} \mathrm{C}$ ), both in first $2 \mathrm{~d}(3.57,95 \% \mathrm{CI} 3.05-4.11)$ and from the third day onwards (i.e. during Heat Waves: 3.43, $95 \% \mathrm{CI} 3.08-3.77)$. Higher risk for OIs was reported in days characterized temperatures $\geq 95$ th percentile (OR 1.145, 95\%CI $1.062-1.235$ ), summer days (daily maximum $\geq 25^{\circ} \mathrm{C}$, OR $1.093,95 \% \mathrm{CI}$ 1.042-1.146). On the contrary, no significant increased risk was found for OIs having a more severe prognosis ( $\geq \mathbf{4 0} \mathrm{d}$ or more; death). In conclusion, presented findings recommend policymakers to develop appropriate procedures and guidelines, in particular aimed to improve the compliance of younger CWs towards severe-hot daily temperatures.
\end{abstract}

Key words: Construction workers, Climate change, Heat exposure, Occupational injuries, Hot weather, Heat wave

\section{Introduction}

During the last decades, climate changes have significantly affected both living and working environments ${ }^{1-3)}$.

*To whom correspondence should be addressed.

E-mail: matteo.ricco@ausl.re.it; mricco2000@gmail.com

(C)2020 National Institute of Occupational Safety and Health
The Fifth Assessment Report (AR5) of the Intergovernmental Panel on Climate Change (IPCC) has estimated that between the 1850-1900 period and the 2003-2012 period average global temperatures have increased of $0.78^{\circ} \mathrm{C}^{4}$, and such transition was associated with a significant surge in both magnitude and frequency of extreme events such as heatwaves (HWs), with an even higher risk for population exposed to Mediterranean-like climates ${ }^{5}$. High environmental temperatures and HWs events have been strongly 
associated with population-level increases in morbidity and mortality for cardiovascular, respiratory and other illnesses, and the climate changes will presumptively increase both the incidence and the severity of these effects ${ }^{6-17)}$.

Because of a combination of external thermal environment, heat sources in the workplace, and internal heat generation by physical activity associated with strenuous muscular work, climate changes and eventual heat exposure represent an even greater challenge to workers' health and safety, especially in persons with pre-existing illnesses ${ }^{2,7,18-28)}$. The risk of heat-related health effects appears significantly increased in outdoors workers, includ-

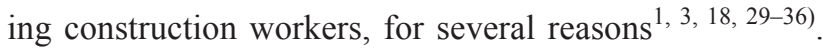
First and foremost, even though the mechanization of many tasks has reduced the strenuous physical labour carried out by construction workers, many activities still requires strenuous manual work. Actually, extensive mechanization requires economic resources that are often beyond the financial capacity of many small companies (i.e. $<10$ employees) ${ }^{30,37,38)}$. Second, due to the physical nature of construction industry, construction workers usually perform their activities outdoors, being poorly protected against meteorological factors such as extreme heat and solar radiation ${ }^{30,39)}$. Third, health and safety training in the construction industry are frequently inadequate, and again small companies are less likely to implement appropriate procedures and guidelines ${ }^{30,32,37-40)}$. Hence, many workers may continue to work beyond a safe heat exposure limit as they are unaware of the risks associated with the heat exposure, or have inappropriate knowledge of the preventive measures, as avoiding the hottest hours of the day for most strenuous physical exertion, or increasing the water intake during the $\mathrm{HWs}^{41,42}$.

Available evidence suggests that heat-related health effects include a significantly increased risk of occupational injuries ${ }^{1,29,30,43,44)}$. As high temperatures can affect cognition, hamper concentration, reduce vigilance and increase fatigue, working during warm weather would ultimately increase the risk of mistakes, accidents and injuries $^{18,35,36,44-46)}$, especially in subjects who otherwise would spend little time outdoor, such as part-time or seasonal workers ${ }^{29}$. Moreover, higher temperatures may force the workers to reduce the use of personal protective equipment, ultimately increasing the risk for incidents associated with the exposure to dusts and chemicals 1, 3, 18, 29-36,43).

As climate change effects gradually progress, the importance of understanding the impact of hot climate on injuries in the construction industry, and preventing them through appropriate preparedness and emergency response plans in the workplace becomes a growing challenge for occupational health and safety ${ }^{1,3}, 18,24,29,32,35$, $36,44,47-49)$. The aim of this study was therefore to assess to what extent Construction workers have been impacted by hot weather in a highly developed settings, i.e. the NorthEastern Italian region of Trentino (Autonomous Province of Trento).

\section{Methods}

\section{Settings}

Autonomous Province of Trento is located in the Italy's North East, covers a total area of $6,214 \mathrm{~km}^{2}(2,399 \mathrm{sq} \mathrm{mi})$ and has a population of 537,416 habitants (2015 census). According to available data and labor force statistics from the Statistical Institute of the Autonomous Province of Trento (ISPAT) in the last decade workforce encompassed around 250,000 adult age subjects per year, and construction industry employed around $9.2 \%$ of total (i.e. around 20,000 adult age subjects/year, $14.8 \%$ of total male workforce $)^{50)}$.

\section{Meteorological data}

Meteorological data, including daily average (Tday), minimum (Tmin), maximum (Tmax) temperatures, air relative humidity, atmospheric pressure, wind speed and solar irradiation for the study period were obtained from the Meteotrentino Service (http://www.meteotrentino.it/dati-meteo/info-dati.aspx?ID=3) of the APT. Meteotrentino Archive includes data from a total of 214 meteorological stations scattered over the provincial area, allowing to direct link geographical site of injury with air temperature at the time of the accident. As data about air relative humidity, wind speed and solar irradiation were not available for all meteorological stations, data from the nearest station at the time of the index injury were ultimately retrieved. Exposure groups were defined as follows. As otherwise suggested $^{49)}$, calendar days were initially categorized by Tmin and Tmax as follows: Frost days (i.e. days with Tmin $<0^{\circ} \mathrm{C}$ ), Summer days (i.e. days with $\operatorname{Tmax}>25^{\circ} \mathrm{C}$ ), Summer days/Tropical Nights (i.e. days with $\operatorname{Tmax}>25^{\circ} \mathrm{C}$ and Tmin $>20^{\circ} \mathrm{C}$ ). Days not included in the aforementioned definition were classified as "Neutral days". Currently, there is no universal definition of a HW, although most studies have defined HW as a combination of duration (e.g. 3 or more days) and intensity (either as Tmax or average daily temperatures) ${ }^{52,53)}$. In order to more easily compare our estimated with previous studies on HWs, an HW event was defined by 3 or more consecutive days having Tmax 
$\geq 35^{\circ} \mathrm{C}^{30,35,36,43)}$. Eventually, in order to assess the effect of average daily temperature, Tday were arbitrarily categorized into the following $<5$ th, $5-24$ th, $25-74$ th, $75-94$ th and $\geq 95$ th percentiles.

\section{Occupational injuries}

Data on occupational injuries for all of Autonomous Province of Trento from 2000 to 2013 were retrieved from the archive of the Operative Unit for Health and Safety in the Workplaces (UOPSAL, Italian acronym), the institutional service representing the local governmental structure for the management and prevention of occupational injuries, occupational diseases, and work-related diseases in the workplaces. Available data were anonymized in order to include only age at the time of the event, sex, and country of birth, and incorporated reference to the geographical site (municipality-level detail) and calendar date of the events, the nature of injury, bodily location, mechanism, and agency of injury/disease. As activities of construction industry are clustered during the warm season, but diffusely performed across the calendar year, we retrieved all available injuries, and excluded all cases that occurred: (a) on to way to/from the workplace (in Italian, "in itinere"); (b) clearly occurred indoors; (c) during weekend and holidays; (d) in days characterized by rain or snow (arbitrary cut-off: $5 \mathrm{~mm}$ ). Similarly, (e) injuries without information on the place of event, and (f) those in the validation phase, were excluded from the analyses.

\section{Ethics}

The study included only a retrospective assessment of data available through an Institutional Database, and the analysis was performed as a part of official duties. Personal data were restricted to information about the occupational injury, and were treated in order to guarantee the respect of privacy of the involved workers, as specifically stated by Italian Law n. 675 of 1996 about personal data protection. Therefore, the study did not require preliminary evaluation by the local Ethical Committee.

\section{Statistical analysis}

Continuous variables were tested for normal distribution (D'Agostino and Pearson omnibus normality test): where the corresponding $p$ value was $<0.10$, normality distribution was assumed as rejected and variables were compared through Mann-Whitney or Kruskal-Wallis test for multiple independent samples. On the other hand, variables passing the normality check (D'Agostino and Pearson $p \geq 0.10$ ) were compared using the Student's $t$-test or ANOVA, where appropriate. Daily rates of occupational injuries were calculated for the study period, by year, by season, by calendar month, and eventually for the exposure groups as previously described. We assumed that the recorded events (i.e., occupational injuries) were mutually independent, and although influenced by demographic factors and by the extent of the activities performed in that time period, eventually related to air temperatures. In order to adjust crude rates for factors having a presumptive effect on the outcome variable injury rate, Odds Ratios (ORs) with their respective 95\% Confidence Intervals $(95 \% \mathrm{CI})$ were calculated for all cases, for cases having a prognosis $\geq 40 \mathrm{~d}$ and with any long-term sequela, as well as by age groups (i.e. $<20 \mathrm{yr}, 20-29 \mathrm{yr}, 30-39 \mathrm{yr}, 40-49 \mathrm{yr}, \geq 50 \mathrm{yr}$ ) and by settings of the injury, through 3 Poisson regression models that included the aforementioned exposure categories as the effector variables, and meteorological data (i.e. air relative humidity, atmospheric pressure, wind speed and solar irradiation) as covariates. In the analyses, we assumed as reference categories: (1) "neutral days" compared to "frost days", "summer days", and "summer days/tropical nights"; (2) days having $\mathrm{T} \max <35^{\circ} \mathrm{C}$ compared to days characterized by $\operatorname{Tmax} \geq 35^{\circ} \mathrm{C}$, either as an isolate exposure, or following 3 or more consecutive days with Tmax $\geq 35^{\circ} \mathrm{C}$ (i.e. HW events); (3) 25-74th Tday percentile vs. all other percentiles. All the analyses were controlled for the number of Construction workers actually active in the construction industry at the time of the reported injury. The models did not include factors such as heat sources in the workplace, noise exposure, type of employment, etc., as not universally available from the reports. All the analyses were performed in SPSS 25 (IBM Corp. Armonk, NY, USA).

\section{Results}

Meteorological data for time period 01/01/2000-31/12/ 2013 are presented in Table 1. Briefly, average Tday was $12.7^{\circ} \mathrm{C}$ (range $-6.2^{\circ} \mathrm{C}$ to $29.9^{\circ} \mathrm{C}$, median $13.1^{\circ} \mathrm{C}$ ), and average values for Tmin and Tmax were $6.5^{\circ} \mathrm{C}\left(-10.5^{\circ} \mathrm{C}\right.$ to $\left.21.0^{\circ} \mathrm{C}\right)$ and $20.5^{\circ} \mathrm{C}\left(0.1^{\circ} \mathrm{C}\right.$ to $\left.41.2^{\circ} \mathrm{C}\right)$, respectively. A total of $246 \mathrm{~d}(10.9 \%)$ fulfilled the working definition of "Frost day", whereas 1,161 (51.4\%) were classified as "Summer days" and $15(0.7 \%)$ as "Summer days/Tropical nights". Of them, $161 \mathrm{~d}$ were characterized by $\mathrm{Tmax}>35^{\circ} \mathrm{C}(5.3 \%)$, with 112 occurring as the third or later during a $\mathrm{HW}$ event.

As shown in Table 2, a total of 20,724 occupational injuries were initially retrieved: after exclusion criteria were applied, a total of 14,072 episodes were analysed: 
Table 1. Descriptive summary of daily meteorological data, Autonomous Province of Trento, 2000 to 2013

\begin{tabular}{|c|c|c|c|c|c|c|c|c|c|c|}
\hline \multirow{2}{*}{ Meteorological measure (unit) } & \multirow{2}{*}{ Min. } & \multirow{2}{*}{ Max. } & \multirow{2}{*}{ Mean } & \multicolumn{7}{|c|}{ Percentiles } \\
\hline & & & & $5 \%$ & $10 \%$ & $25 \%$ & $50 \%$ & $75 \%$ & $90 \%$ & $95 \%$ \\
\hline Maximum daily temperature $\left({ }^{\circ} \mathrm{C}\right)$ & 0.1 & 41.2 & 20.5 & 5.7 & 7.5 & 12.1 & 21.4 & 28.6 & 32.3 & 33.9 \\
\hline Minimum daily temperature $\left({ }^{\circ} \mathrm{C}\right)$ & -10.5 & 21 & 6.5 & -5.6 & -3.6 & -0.4 & 6.8 & 13.1 & 16.7 & 17.9 \\
\hline Average daily temperature $\left({ }^{\circ} \mathrm{C}\right)$ & -6.2 & 29.9 & 12.7 & -0.6 & 1.2 & 4.9 & 13.1 & 20.1 & 24 & 25.3 \\
\hline Difference with average temperatures $\left({ }^{\circ} \mathrm{C}\right)$ & -11.8 & 11.7 & 1.2 & -3.9 & -2.7 & -0.7 & 1.3 & 3.3 & 5.1 & 6.1 \\
\hline Relative humidity (\%) & 14.8 & 100 & 65.5 & 38.4 & 44.8 & 55.1 & 64.6 & 73.3 & 83.1 & 88.4 \\
\hline Solar radiation $\left(\mathrm{kJ} / \mathrm{m}^{2}\right)$ & 60 & 245,443 & 13,867 & 1,179 & 2,064 & 3,373 & 7,177 & 12,506 & 19,854 & 23,789 \\
\hline Atmospheric pressure $(\mathrm{hPa})$ & 911.2 & $1,021.7$ & 985.1 & 967.6 & 974.1 & 981.8 & 987.1 & 992.3 & 998.5 & 1002.9 \\
\hline Wind Speed $(m * s-1)$ & 0.1 & 7.6 & 1.5 & 0.6 & 0.7 & 0.9 & 1.4 & 1.9 & 2.3 & 2.6 \\
\hline
\end{tabular}

Table 2. Number and characteristics of acute work-related injuries in the construction industries, Autonomous Province of Trento (2000-2013)

\begin{tabular}{llrr}
\hline & Variable & No. & $\%$ \\
\hline Occupational injuries & All recorded events, 2000 to 2013 & 20,724 & 100 \\
& Included in the final analysis & 14,072 & 67.9 \\
\hline \multirow{2}{*}{ Gender } & Male & 13,931 & 99 \\
& Female & 141 & 1 \\
\hline Migration background & No (Italian-born People) & 10,878 & 77.3 \\
& Yes (Foreign-born People) & 3,194 & 22.7 \\
\hline \multirow{2}{*}{ Age group (yr) } & $\leq 20$ & 743 & 5.3 \\
& $20-29$ & 3,632 & 32.5 \\
& $30-39$ & 4.156 & 23.2 \\
& $40-49$ & 3,378 & 12 \\
& $\geq 50$ & 2,163 & 15.4 \\
\hline Prognosis (d) & $\geq 40$ d & 2,396 & 17 \\
& Any long-term sequela & 1,814 & 12.9 \\
\hline Characteristics of the injury & Falls, in general & 2,973 & 21.1 \\
& Falls from height $>2$ m & 929 & 6.6 \\
& Distraction/carelessness during usual tasks & 2,448 & 17.4 \\
& Use of tools/machineries & 2,481 & 17.6 \\
& Manual handling & 865 & 6.1 \\
\hline
\end{tabular}

the majority of them occurred in construction workers that were $<40 \mathrm{yr}$-old at the time of the injury $(61 \%$; mean age $36.7 \pm 11.4 \mathrm{yr})$, and in subjects of Italian origin $(77.3 \%)$. The final sample included 13,931 males $(99.0 \%$; mean age: $36.7 \pm 11.4 \mathrm{yr})$, and 141 females $(1.0 \%$; mean age: $36.6 \pm 10.9 \mathrm{yr}$ ), of similar age ( $>0.05)$. In 2,396 cases $(17.0 \%)$, the occupational injury had a prognosis $\geq 40 \mathrm{~d}$, with long-term sequelae in $12.9 \%$ of all cases. The majority of occupational injuries included in the analyses occurred as falls $(21.1 \%)$, with a third of them $(6.6 \%$ of total sample) from height $>2 \mathrm{~m}$, followed by injuries involving the use of tools and/or machineries (17.6\%), inattention (i.e. distraction and/or carelessness) during usual tasks (17.4\%), and tasks requiring manual handling (6.1\%).

Estimated incidence of occupational injuries during the study period was 5.7 events by day (95\%CI 5.5-5.8), with an estimated cumulative incidence of 2.8 episodes $/ 10,000$ workers/d (95\%CI 2.7-2.9). As shown in Table 3, daily incidence of work accidents significantly decreased between 2000 and 2013 (ANOVA test for trend $<0.001$ ), whereas the ratio between injuries with prognosis $\geq 40 \mathrm{~d}$ and total injuries ranged from a minimum of $14.9 \%(95 \% \mathrm{CI}$ $12.7-17.2)$ in 2000 , to the maximum of $20.3 \%$ (95\% CI 17.5-23.0) in 2004 without a clear time trend. On the contrary, a time trend was identified across the calendar year, with higher shares for the winter months of November (20.0\%, 95\%CI 17.4-22.5) and December $(22.8 \%, 95 \%$ CI 19.1-26.5). Overall (Table 4), daily rates of injuries were significantly higher in Summer days than in reference to Neutral ones $(3.20,95 \%$ CI $3.11-3.30$ vs. $3.02,95 \%$ CI 
Table 3. Rates of occupational injuries (OIs) in the construction industries, for all cases and for cases having prognosis $\geq \mathbf{4 0} \mathrm{d}$, and their ratio, by year and month of occurrence

\begin{tabular}{|c|c|c|c|}
\hline & $\begin{array}{c}\text { All OIs } \\
\text { (No./10,000 person-day) }\end{array}$ & $\begin{array}{l}\text { OIs with prognosis } \geq 40 \mathrm{~d} \\
\text { (No./10,000 person-day) }\end{array}$ & $\begin{array}{l}\text { Ratio OIs with prognosis } \\
\geq 40 \mathrm{~d} / \text { all OIs }(\%)\end{array}$ \\
\hline \multicolumn{4}{|c|}{ Year of Occurrence } \\
\hline 2000 & $3.78(3.56 ; 4.01)$ & $0.60(0.53 ; 0.68)$ & $16.4(14.2 ; 18.7)$ \\
\hline 2001 & $3.42(3.21 ; 3.63)$ & $0.50(0.43 ; 0.57)$ & $14.9(12.7 ; 17.2)$ \\
\hline 2002 & $3.16(2.97 ; 3.36)$ & $0.52(0.45 ; 0.60)$ & $15.7(13.4 ; 18.0)$ \\
\hline 2003 & $3.33(3.13 ; 3.52)$ & $0.59(0.52 ; 0.65)$ & $17.8(15.6 ; 20.0)$ \\
\hline 2004 & $3.43(3.21 ; 3.65)$ & $0.62(0.56 ; 0.69)$ & $20.3(17.5 ; 23.0)$ \\
\hline 2005 & $3.49(3.28 ; 3.70)$ & $0.56(0.49 ; 0.63)$ & $16.4(14.2 ; 18.5)$ \\
\hline 2006 & $3.35(3.13 ; 3.56)$ & $0.58(0.51 ; 0.65)$ & $17.8(15.3 ; 20.2)$ \\
\hline 2007 & $2.97(2.79 ; 3.16)$ & $0.56(0.49 ; 0.62)$ & $19.7(17.1 ; 22.3)$ \\
\hline 2008 & $2.55(2.38 ; 2.73)$ & $0.45(0.39 ; 0.50)$ & $18.4(15.6 ; 21.3)$ \\
\hline 2009 & $2.25(2.09 ; 2.42)$ & $0.40(0.34 ; 0.45)$ & $17.7(15.0 ; 20.4)$ \\
\hline 2010 & $2.48(2.30 ; 2.66)$ & $0.49(0.42 ; 0.56)$ & $19.7(16.6 ; 22.9)$ \\
\hline 2011 & $1.91(1.77 ; 2.05)$ & $0.38(0.33 ; 0.44)$ & $18.9(16.0 ; 21.8)$ \\
\hline 2012 & $1.59(1.46 ; 1.72)$ & $0.27(0.22 ; 0.32)$ & $16.0(12.8 ; 19.2)$ \\
\hline 2013 & $1.39(1.25 ; 1.52)$ & $0.29(0.23 ; 0.36)$ & $18.4(14.2 ; 22.6)$ \\
\hline \multicolumn{4}{|c|}{ Month of Occurrence } \\
\hline Jan. & $1.65(1.52 ; 1.79)$ & $0.32(0.27 ; 0.36)$ & $17.2(14.4 ; 20.1)$ \\
\hline Feb. & $2.18(2.03 ; 2.33)$ & $0.41(0.27 ; 0.47)$ & $19.5(16.4 ; 22.5)$ \\
\hline Mar. & $2.74(2.58 ; 2.91)$ & $0.50(0.44 ; 0.56)$ & $17.6(15.3 ; 19.8)$ \\
\hline Apr. & $2.86(2.69 ; 3.04)$ & $0.48(0.42 ; 0.54)$ & $16.9(14.7 ; 19.2)$ \\
\hline May & $3.36(3.16 ; 3.56)$ & $0.52(0.45 ; 0.59)$ & $14.7(12.8 ; 16.7)$ \\
\hline Jun. & $3.53(3.34 ; 3.73)$ & $0.57(0.51 ; 0.63)$ & $16.7(14.6 ; 18.8)$ \\
\hline Jul. & $3.61(3.40 ; 3.82)$ & $0.55(0.49 ; 0.61)$ & $16.1(14.0 ; 18.1)$ \\
\hline Aug. & $2.23(2.05 ; 2.42)$ & $0.34(0.28 ; 0.39)$ & $14.8(12.1 ; 17.6)$ \\
\hline Sep. & $3.32(3.14 ; 3.50)$ & $0.59(0.52 ; 0.65)$ & $18.4(16.3 ; 20.6)$ \\
\hline Oct. & $3.08(2.90 ; 3.25)$ & $0.54(0.48 ; 0.61)$ & $18.2(16.1 ; 20.3)$ \\
\hline Nov. & $3.04(2.83 ; 3.25)$ & $0.60(0.53 ; 0.67)$ & $20.0(17.4 ; 22.5)$ \\
\hline Dec. & $2.12(1.93 ; 2.31)$ & $0.47(0.40 ; 0.53)$ & $22.8(19.1 ; 26.5)$ \\
\hline
\end{tabular}

All data are presented with their respective $95 \%$ Confidence Intervals.

2.92-3.12), whereas a significantly lower rate was identified for Frost days $(2.78,95 \%$ CI 2.59-2.96). Similarly, when compared with days having Tmax $<35^{\circ} \mathrm{C}(2.77$, $95 \%$ CI $2.71-2.83$ ), days characterized by a $\operatorname{Tmax} \geq 35^{\circ} \mathrm{C}$ were associated with higher rates for occupational injuries, both for exposures $<3$ days $(3.57,95 \%$ CI $3.05-4.11)$, and from the third day onwards (i.e. HW time periods, 3.43 , 95\% CI 3.08-3.77).

In regression analysis, a significantly higher risk for occupational injuries was associated to the Summer days (OR $1.093,95 \%$ CI $1.042-1.146$ ) and to days having a Tmax $\geq 35^{\circ} \mathrm{C}$, both for exposures shorter than 3 consecutive days (OR 1.276, 95\% CI 1.147-1.418) or equals to/longer than 3 consecutive days (OR 1.230, 95\%CI 1.144-1.322). More specifically, higher risks for occupational injuries in subjects $<20 \mathrm{yr}$-old at the time of the event were reported in days fulfilling Summer day and Summer day/Tropical night definition (OR 1.302, 95\%CI 1.040-1.630, and OR 3.493, 1.417-8.612, respectively). Similarly, days having a Tmax $\geq 35^{\circ} \mathrm{C}$ were characterized by an increased risk for injuries in all subjects $<50 \mathrm{yr}$-old, while no significant differences were reported in older age groups (OR 0.935 95\%CI $0.684-1.278$ for exposure lags $<3$ consecutive days, and $1.156,95 \%$ CI $0.958-1.396$ for exposure lags $\geq 3$ consecutive days).

Focusing on low temperatures, Frost days were associated with a significantly reduced risk (OR $0.892,95 \% \mathrm{CI}$ 0.831-0.957), in particular for subjects 20-29 yr-old (OR $0.822,95 \%$ CI $0.712-0.951)$ and $30-39$ yr-old $(0.779$, 95\% CI 0.680-0.891) (Table 5). However, when focusing on the severity of the injuries (i.e. prognosis $\geq 40 \mathrm{~d}$, evidence of long-term sequelae), no significant difference was found. 
Table 4. Rates of occupational injuries (OIs) in the construction industries throughout the classification of reported days by meteorological data

\begin{tabular}{lcc}
\hline & OIs & $p$ value \\
\hline Neutral day $\left(\operatorname{Tmin}>0.0^{\circ} \mathrm{C}, \operatorname{Tmax}<25.0^{\circ} \mathrm{C}\right)$ & $($ No./10,000 person-day) & - \\
Frost days $\left(\operatorname{Tmin}<0.0^{\circ} \mathrm{C}\right)$ & $3.02(2.92 ; 3.12)$ & $<0.001$ \\
Summer days $\left(\operatorname{Tmax} \geq 25.0^{\circ} \mathrm{C}\right)$ & $2.78(2.59 ; 2.96)$ & $<0.001$ \\
Summer days, tropical nights $\left(\operatorname{Tmax}>25.0^{\circ} \mathrm{C}\right.$, Tmin $\left.>20.0^{\circ} \mathrm{C}\right)$ & $3.20(3.11 ; 3.30)$ & 0.917 \\
Classification by Heat Waves Event & $3.11(2.02 ; 4.20)$ & - \\
Days with Tmax $<35^{\circ} \mathrm{C}$ & & $<0.001$ \\
Heat Wave, First $2 \mathrm{~d}$ & $2.77(2.71 ; 2.83)$ & 0.001 \\
\hline Heat Wave, from 3rd day onwards & $3.57(3.05 ; 4.11)$ & $3.43(3.08 ; 3.77)$ \\
\hline
\end{tabular}

All data are presented with their respective $95 \%$ Confidence Intervals.

Table 5. Risk of occupational injuries (OIs) in the construction industries, throughout the classification of calendar day by meteorological data

\begin{tabular}{|c|c|c|c|c|c|}
\hline & $\mathrm{T} \max \geq 35^{\circ} \mathrm{C}$ & $\mathrm{T} \max \geq 35^{\circ} \mathrm{C}$ & & & \\
\hline & $\begin{array}{c}\text { Less than } 3 \\
\text { consecutive days }\end{array}$ & $\begin{array}{c}\text { 3rd consecutive day } \\
\text { and onwards }\end{array}$ & Frost days & Summer days & Tropical nights \\
\hline All cases & $1.276(1.147 ; 1.418)$ & $1.230(1.144 ; 1.322)$ & $0.892(0.831 ; 0.957)$ & $1.093(1.042 ; 1.146)$ & $1.063(0.778 ; 1.454)$ \\
\hline prognosis $\geq 40 \mathrm{~d}$ & $0.995(0.748 ; 1.324)$ & $1.080(0.899 ; 1.297)$ & $1.121(0.961 ; 1.307)$ & $0.997(0.891 ; 1.116)$ & $0.585(0.218 ; 1.568)$ \\
\hline long-term sequelae & 0.881 (0.622: 1.249) & $1.181(0.964 ; 1.446)$ & $0.959(0.800 ; 1.150)$ & $1.005(0.887 ; 1.139)$ & $0.729(0.272 ; 1.955)$ \\
\hline \multicolumn{6}{|l|}{ Age groups } \\
\hline$<20 \mathrm{yr}$ & $1.640(1.074 ; 2.505)$ & $1.892(1.449 ; 2.470)$ & $0.815(0.575 ; 1.155)$ & $1.302(1.040 ; 1.630)$ & $3.493(1.417 ; 8.612)$ \\
\hline $20-29 \mathrm{yr}$ & $1.462(1.203 ; 1.776)$ & $1.125(1.971 ; 1.305)$ & $0.822(0.712 ; 0.951)$ & $1.048(0.953 ; 1.152)$ & $1.043(0.558 ; 1.950)$ \\
\hline $30-39 \mathrm{yr}$ & $1.219(1.000 ; 1.486)$ & $1.168(1.020 ; 1.337)$ & $0.779(0.680 ; 0.891)$ & $1.065(0.976 ; 1.162)$ & $1.185(0.684 ; 2.053)$ \\
\hline $40-49 \mathrm{yr}$ & $1.280(1.030 ; 1.591)$ & $1.323(1.146 ; 1.527)$ & $0.952(0.829 ; 1.094)$ & $1.134(1.032 ; 1.246)$ & $0.938(0.485 ; 1.813)$ \\
\hline$\geq 50 \mathrm{yr}$ & $0.935(0.684 ; 1.278)$ & $1.156(0.958 ; 1.396)$ & $1.167(0.986 ; 1.381)$ & $1.107(0.981 ; 1.249)$ & $0.502(0.161 ; 1.565)$ \\
\hline \multicolumn{6}{|l|}{ Injuries } \\
\hline Falls & $1.087(0.847 ; 1.395)$ & $1.276(1.093 ; 1.489)$ & $1.010(0.885 ; 1.152)$ & $1.046(0.950 ; 1.152)$ & $1.074(0.591 ; 1.952)$ \\
\hline Falls from height & $1.169(0.759 ; 1.800)$ & $1.339(1.021 ; 1.756)$ & $0.899(0.704 ; 1.147)$ & $1.080(0.910 ; 1.283)$ & $0.649(0.161 ; 2.617)$ \\
\hline Inattention & $1.001(0.753 ; 1.332)$ & $1.077(0.896 ; 1.295)$ & $1.178(1.020 ; 1.359)$ & $1.041(0.939 ; 1.154)$ & $1.030(0.533 ; 1.993)$ \\
\hline Use of tools/machineries & $1.090(0.831 ; 1.431)$ & $1.170(0.981 ; 1.395)$ & $0.756(0.638 ; 0.896)$ & $1.158(1.037 ; 1.293)$ & $1.534(0.842 ; 2.794)$ \\
\hline Manual handling & $1.398(0.932 ; 2.095)$ & $1.045(0.764 ; 1.427)$ & $0.876(0.687 ; 1.116)$ & $0.942(0.796 ; 1.115)$ & $1.588(0.652 ; 3.866)$ \\
\hline
\end{tabular}

All data are presented as Odds Ratios with their respective $95 \%$ Confidence Intervals.

Frost days: days having minimum daily temperature $<0^{\circ} \mathrm{C}$.

Summer days: days having maximum daily temperature $>25^{\circ} \mathrm{C}$.

Summer days, tropical nights: days having maximum daily temperature $>25^{\circ} \mathrm{C}$, and minimum daily temperature $>20^{\circ} \mathrm{C}$.

Regarding the mechanism of the injuries, an increased risk was reported for inattention during usual tasks performed in Frost days (OR 1.178, 95\%CI 1.020-1.359), and for the use of tools/machineries in Summer days (OR 1.158, 95\% CI 1.037-1.293), whereas a significantly reduced risk was identified for injuries associated with the handling of tools/machineries during Frost days (OR $0.756,95 \% \mathrm{CI}$ $0.638-0.896)$. Interestingly enough, exposures to Tmax $\geq 35^{\circ} \mathrm{C}$ for 3 consecutive days or more during HW were associated with increased risks of falls (OR 1.276, 95\% CI 1.093-1.489), and falls from height (OR $1.339,95 \% \mathrm{CI}$ 1.021-1.756), and such effect was not reported for shorter exposures.
Table 6 shows the risk for injuries broken down by daily exposure groups, for the whole study period. A more complex patter was identified. More specifically, the risk was significantly higher for exposures $>95$ th percentile (OR $1.145,95 \%$ CI $1.062-1.235)$, particularly among workers aged $<20 \mathrm{yr}$ (OR 1.902, 95\% 1.393-2.599) and 40 to $49 \mathrm{yr}$ (OR 1.177, 95\% CI 1.016-1.365). On the contrary, a somehow protective effect towards injuries was found for Tday 10th to 24th percentile (OR $0.851,95 \%$ CI $0.782-0.927$ ), particularly in age groups 20 to $49 \mathrm{yr}$, while a seemly increased risk was identified for Construction workers aged $50 \mathrm{yr}$ or more (OR 1.232, 95\%CI 1.017-1.494). Similarly, a reduced risk for occupational injuries was 
Table 6. Risk of occupational injuries (OIs) in the construction industries, throughout the classification of calendar day by Tday percentiles

\begin{tabular}{|c|c|c|c|c|c|c|}
\hline & \multicolumn{6}{|c|}{ Percentiles of Tday } \\
\hline & $<5 \%$ & $5-9 \%$ & $10-24 \%$ & $75-89 \%$ & $90-95 \%$ & $>95 \%$ \\
\hline All cases & $0.854(0.746 ; 0.978)$ & $0.972(0.820 ; 1.152)$ & $0.851(0.782 ; 0.927)$ & $1.050(0.995 ; 1.109)$ & $1.074(0.992 ; 1.162)$ & $1.145(1.062 ; 1.235)$ \\
\hline prognosis $\geq 40 \mathrm{~d}$ & $0.930(0.683 ; 1.267)$ & $1.448(1.035 ; 2.026)$ & $1.129(0.944 ; 1.350)$ & $1.006(0.884 ; 1.145)$ & $0.863(0.703 ; 1.058)$ & $0.985(0.816 ; 1.190)$ \\
\hline long-term sequelae & $0.805(0.557 ; 1.164)$ & $1.168(0.769 ; 1.773)$ & $1.021(0.829 ; 1.258)$ & $1.073(0.932 ; 1.235)$ & $0.846(0.672 ; 1.063)$ & $0.970(0.785 ; 1.199)$ \\
\hline \multicolumn{7}{|l|}{ Age groups } \\
\hline$<20 \mathrm{yr}$ & $0.838(0.442 ; 1.589)$ & $1.520(0.776 ; 2.975)$ & $0.730(0.476 ; 1.120)$ & $1.172(0.907 ; 1.515)$ & $1.696(1.222 ; 1.235)$ & $1.902(1.393 ; 2.599)$ \\
\hline $20-29 \mathrm{yr}$ & $0.603(0.439 ; 0.827)$ & $0.744(0.508 ; 1.091)$ & $0.815(0.687 ; 0.966)$ & $0.996(0.892 ; 1.111)$ & $1.059(0.903 ; 1.241)$ & $1.120(0.962 ; 1.303)$ \\
\hline $30-39 \mathrm{yr}$ & $0.866(0.679 ; 1.104)$ & $0.924(0.674 ; 1.267)$ & $0.734(0.624 ; 0.863)$ & $1.033(0.935 ; 1.142)$ & $1.037(0.894 ; 1.202)$ & $1.021(0.882 ; 1.182)$ \\
\hline $40-49 \mathrm{yr}$ & $1.036(0.810 ; 1.326)$ & $0.857(0.599 ; 1.226)$ & $0.837(0.706 ; 0.992)$ & $1.102(0.992 ; 1.225)$ & $1.034(0.882 ; 1.212)$ & $1.177(1.016 ; 1.365)$ \\
\hline$\geq 50 \mathrm{yr}$ & $0.960(0.685 ; 1.345)$ & $1.519(1.057 ; 2.181)$ & $1.232(1.017 ; 1.494)$ & $1.061(0.925 ; 1.218)$ & $1.084(0.888 ; 1.323)$ & $1.187(0.984 ; 1.432)$ \\
\hline \multicolumn{7}{|c|}{ (2) } \\
\hline Falls & $1.135(0.898 ; 1.435)$ & $1.176(0.889 ; 1.556)$ & $0.891(0.761 ; 1.044)$ & $1.007(0.901 ; 1.126)$ & $0.855(0.715 ; 1.022)$ & $1.056(0.902 ; 1.236)$ \\
\hline Falls from height & $0.522(0.286 ; 0.951)$ & $0.865(0.485 ; 1.543)$ & $0.897(0.681 ; 1.182)$ & $0.922(0.751 ; 1.132)$ & $1.085(0.812 ; 1.448)$ & $1.118(0.849 ; 1.472)$ \\
\hline Inattention & $1.325(1.039 ; 1.688)$ & $1.201(0.856 ; 1.685)$ & $1.033(0.866 ; 1.233)$ & $0.970(0.862 ; 1.091)$ & $0.920(0.773 ; 1.096)$ & $1.047(0.891 ; 1.231)$ \\
\hline Use of tool/machineries & $0.559(0.383 ; 0.815)$ & $0.776(0.516 ; 1.167)$ & $0.772(0.635 ; 0.938)$ & $1.109(0.979 ; 1.257)$ & $1.207(1.009 ; 1.445)$ & $1.154(0.966 ; 1.378)$ \\
\hline Manual handling & $0.781(0.473 ; 1.291)$ & $0.752(0.387 ; 1.461)$ & $0.987(0.752 ; 1.295)$ & $0.876(0.714 ; 1.076)$ & $1.000(0.746 ; 1.340)$ & $1.093(0.831 ; 1.438)$ \\
\hline
\end{tabular}

All data are presented as Odds Ratios with their respective 95\% Confidence Intervals.

also identified for exposures $<5$ th percentile (OR 0.854 , $95 \%$ CI $0.746-0.978$ ), but only for age group 20 to $29 \mathrm{yr}$ (0.603; 95\%CI 0.439-0.827), and for accidents resulting from falls from height (OR 0.522, 95\% CI 0.286-0.951), and use of tools (OR $0.559,95 \%$ CI $0.383-0.815$ ), while the occurrence injuries associated with inattention was somehow increased (OR 1.325, 95\%CI 1.039-1.688).

\section{Conclusions}

Our results reaffirm that weather conditions and the incidence of occupational accidents in the construction industry are associated in a "J-shaped" curve relationship, in which lower risk is found for colder days, while higher rates are reported in hottest calendar days and during HW events, in particular at its beginning, and for injuries associated with falls and falls from height.

Our report is therefore consistent with previous reports suggesting that hot weather conditions might represent

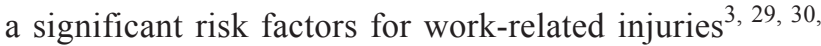
$35,36,43-45)$. As previously reported, higher risk for work related accidents is reported in days characterized by severe but not extreme thermal conditions (i.e. "inverted $U$ shaped curve"), while either extreme hot or cold weather have lower incidence rates ${ }^{29,41,43,44)}$. Usually, such trends are explained as a behavioral adaptation: i.e. workers would avoid most strenuous activities during the hottest days and/or the hottest hours of the working day during the warm season and, similarly, coldest days of the cold season would be perceived as inappropriate to perform outdoor activities $^{29,45)}$. In this regard, it should be recalled that in most high-income countries, hottest months of the warm season are usually associated with holidays, and vacations may further contribute to the reduced number of reported events ${ }^{3,29,36,44,45)}$. Not coincidentally, also in our study lower incidence rates were reported for the month of August. These inconsistencies may be explained recalling some specificities of the Italian construction industry during the last decades. The construction industry has been severely hit by the economic crisis kicked off in 2008 by the problems in the US subprime housing market: also in Italy, around $20 \%$ of total workforce was lost in the time period 2008-2013, and a more severe decrease was reported for the total economic turnover $(-21.1 \%)$. It is possible that resilient companies may have increasingly endured available orders, extending working activities also in uncomfortable weather conditions, exposing construction workers to extreme daily temperatures ${ }^{53,54)}$.

However, we also possibly identified a sort of behavioral adaptation to severe climates. First at all, higher rates for occupational injuries occurred in very hot (Tmax $\geq 35^{\circ} \mathrm{C}$ ) calendar days unrelated with or at the beginning of a HW period. It is reasonable that workers may initially overlook uncomfortable weather condition as a rather common event, particularly during the hot season, while the persistent exposure to high environmental temperature would elicit a more cautious conduct ${ }^{43}$. Similarly, it is reasonable that our results may have been affected by 
the "harvesting" effect that has been usually associated with HW in the general population: i.e. people bearing specific individual risk factors are massively affected by environmental heat in the first days of the HW event, with subsequently higher but transient incidence rates for the assessed outcome (i.e. occupational injuries, in our study) ${ }^{6,13,16,17)}$.

Second, as the increased risk mainly involved accidents having a prognosis $<40 \mathrm{~d}$, i.e. minor trauma, or followed falls and falls from height, some kind of adaptation towards uncomfortable temperatures may be supposed ${ }^{18,35,36,43-46)}$. In other words, being exposed workers unable to restrain from all daily tasks, they would avoid those perceived as more dangerous or less compatible with weather conditions as requiring a more strenuous physical effort, or the wearing of insulating personal protective equipment ${ }^{53,55)}$.

Third, the majority of recorded occupational injuries occurred in subjects who were $<40$ yr-old at the time of the event $(63.2 \%)$, while a greater risk was reported for all age groups younger of $50 \mathrm{yr}$ at the time of a HW event. As younger age groups in the Autonomous Province of Trento would represent only the $47.0 \%$ of total workforce, it is reasonable that our results may have been extensively affected by the experience of the Construction workers towards extreme climates ${ }^{30,31,39,49)}$.

Generalization of our results is impaired by several significant limitations. Firstly, it should be stressed that weather conditions such as radiant heat, air humidity, wind speed and solar irradiation, in a mountainous region such as the Autonomous Province of Trento, air humidity and solar irradiation may strikingly fluctuate over a restricted area because of the altitude ${ }^{3,29,43-45)}$. In other terms, whereas an assessment at municipality level may guarantee a sufficient detail for air temperature, in the settings of our survey it might be not so accurate for other factors ${ }^{41,51-53,55,56)}$. Moreover, as available data about air humidity, wind speed and solar irradiation are more diffusely scattered over the area of APT, their inclusion in the exposure assessment may have increased its inaccuracy.

Second, also the data regarding the work-related accidents are affected by some inaccuracies. Available information about occupational injuries were retrieved from an institutional database, whose content did include neither clinical data nor an accurate description of the level of physical activity performed at the time of the event, the type of clothing, and hydration status, and these factors significantly affect the risk for heat related health effects $^{29,43,44,57)}$. For instance, a recent study performed on the same geographical region hinted towards a possible increased risk for occupational injuries during the Ramadan time period for migrant workers of North-African and Middle-Eastern descent ${ }^{57}$. Even our settings classification is rather coarse. For example, falls may occur while performing other tasks, both manual handling and the use of tools and/or machinery include very heterogeneous tasks, in particular in the construction industry, not necessarily associated with risk factors for heat, and labelling an accident as following "inattention" may only represent a sort of umbrella definition for injuries lacking a more accurate description. Moreover, all classifications we reported may have been somehow interconnected, eventually inflating the inaccuracy of our estimates ${ }^{41,57)}$.

Third, our data are affected by implicit incompleteness about the total number of subjects actually employed in construction industry at the time of the event. As we included in our analyses the number of workers employed by calendar year, both underestimation of actual rates of occupational injuries during hottest days and their overestimation during intermediate days are possible ${ }^{41,43}$.

In conclusion, our data confirm previous reports from the construction industries that extreme weather may be associated with increased risk of occupational injuries, particularly at the beginning of HW events. Collectively, such results stress the importance and the urgent need for the active implementation of appropriate procedures and guidelines even in highly developed settings. On the one hand, policymakers should generally improve the compliance of younger workers towards severe-hot daily temperatures, promoting appropriate habits such as restraining from more dangerous and effort-demanding tasks. On the other hand, competent authorities must be aware that even first days of HWs are associated with unfavourable outcomes, therefore promoting timely countermeasures, that ranges from an early warning to the partial suspension of activities in the construction sites.

\section{Disclosures}

The facts, conclusions, and opinions stated in the article represent the authors' research, conclusions, and opinions and are believed to be substantiated, accurate, valid, and reliable. However, as this article includes the results of personal researches of the Authors, presenting correspondent, personal conclusions and opinions, parent employers are not forced in any way to endorse or share its content and its potential implications. 


\section{References}

1) McInnes JA, Akram M, MacFarlane EM, Keegel T, Sim MR, Smith P (2017) Association between high ambient temperature and acute work-related injury: a case-crossover analysis using workers' compensation claims data. Scand J Work Environ Health 43, 86-94. [Medline] [CrossRef]

2) Kjellstrom T, Holmer I, Lemke B (2009) Workplace heat stress, health and productivity - an increasing challenge for low and middle-income countries during climate change. Glob Health Action 2, 2. [Medline] [CrossRef]

3) Xiang J, Bi P, Pisaniello D, Hansen A (2014) Health impacts of workplace heat exposure: an epidemiological review. Ind Health 52, 91-101. [Medline] [CrossRef]

4) IPCC 2014: Climate Change 2014: Synthesis Report. Contribution of Working Groups I, II and III to the Fifth Assessment Report of the Intergovernmental Panel on Climate Change IPCC, Geneva, Switzerland, p 151. https:// www.ipcc.ch/site/assets/uploads/2018/02/SYR_AR5 FINAL full.pdf. Accessed December 28, 2018.

5) Stoecklin-Marois M, Hennessy-Burt T, Mitchell D, Schenker M (2013) Heat-related illness knowledge and practices among California hired farm workers in The MICASA Study. Ind Health 51, 47-55. [Medline] [CrossRef]

6) Semenza JC, McCullough JE, Flanders WD, McGeehin MA, Lumpkin JR (1999) Excess hospital admissions during the July 1995 heat wave in Chicago. Am J Prev Med 16, 269-77. [Medline] [CrossRef]

7) Gubernot DM, Anderson GB, Hunting KL (2015) Characterizing occupational heat-related mortality in the United States, 2000-2010: an analysis using the Census of Fatal Occupational Injuries database. Am J Ind Med 58, 203-11. [Medline] [CrossRef]

8) Madrigano J, Ito K, Johnson S, Kinney PL, Matte T (2015) A case-only study of vulnerability to heat wave-related mortality in New York City (2000-2011). Environ Health Perspect 123, 672-8. [Medline] [CrossRef]

9) Lin YK, Chang CK, Wang YC, Ho TJ (2013) Acute and prolonged adverse effects of temperature on mortality from cardiovascular diseases. PLoS One 8, e82678-8. [Medline] [CrossRef]

10) Li Y, Cheng Y, Cui G, Peng C, Xu Y, Wang Y, Liu Y, Liu J, Li C, Wu Z, Bi P, Jin Y (2014) Association between high temperature and mortality in metropolitan areas of four cities in various climatic zones in China: a time-series study. Environ Health 13, 65. [Medline] [CrossRef]

11) Bobb JF, Obermeyer Z, Wang Y, Dominici F (2014) Causespecific risk of hospital admission related to extreme heat in older adults. JAMA 312, 2659-67. [Medline] [CrossRef]

12) Harlan SL, Chowell G, Yang S, Petitti DB, Morales Butler EJ, Ruddell BL, Ruddell DM (2014) Heat-related deaths in hot cities: estimates of human tolerance to high temperature thresholds. Int J Environ Res Public Health 11, 3304-26. [Medline] [CrossRef]
13) Semenza JC, Rubin CH, Falter KH, Selanikio JD, Flanders WD, Howe HL, Wilhelm JL (1996) Heat-related deaths during the July 1995 heat wave in Chicago. N Engl J Med 335, 84-90. [Medline] [CrossRef]

14) Åström DO, Forsberg B, Rocklöv J (2011) Heat wave impact on morbidity and mortality in the elderly population: a review of recent studies. Maturitas 69, 99-105. [Medline] [CrossRef]

15) Kosatsky $\mathrm{T}$ (2005) The 2003 European heat waves. Euro Surveill 10, 552. [CrossRef]

16) Michelozzi P, deDonato F, Bisanti L, Russo A, Cadum E, DeMaria M, D'Ovidio M, Costa G, Perucci CA (2005) The impact of the summer 2003 heat waves on mortality in four Italian cities. Euro Surveill 10, 556. [CrossRef]

17) Pirard P, Vandentorren S, Pascal M, Laaidi K, Le Tertre A, Cassadou S, Ledrans M (2005) Summary of the mortality impact assessment of the 2003 heat wave in France. Euro Surveill 10, 153-6. [Medline] [CrossRef]

18) Xiang J, Hansen A, Pisaniello D, Bi P (2016) Workers' perceptions of climate change related extreme heat exposure in South Australia: a cross-sectional survey. BMC Public Health 16, 549. [Medline] [CrossRef]

19) Majumder J, Bagepally BS, Shah P, Kotadiya S, Yadav S, Naha N (2016) Comparison of workers' perceptions toward work climate and health symptoms between ceramic and iron foundry workers. Indian J Occup Environ Med 20, 48-53. [Medline] [CrossRef]

20) Kjellström T, Sawada S, Bernard TE, Parsons K, Rintamäki H, Holmér I (2013) Climate change and occupational heat problems. Ind Health 51, 1-2. [Medline] [CrossRef]

21) Kjellstrom T, Briggs D, Freyberg C, Lemke B, Otto M, Hyatt O (2016) Heat, human performance, and occupational health: a key issue for the assessment of global climate change impacts. Annu Rev Public Health 37, 97-112. [Medline] [CrossRef]

22) Zhou L, Xin Z, Bai L, Wan F, Wang Y, Sang S, Liu S, Zhang J, Liu Q (2014) Perceptions of heat risk to health: a qualitative study of professional bus drivers and their managers in Jinan, China. Int J Environ Res Public Health 11, 1520-35. [Medline] [CrossRef]

23) Adam-Poupart A, Smargiassi A, Busque MA, Duguay P, Fournier M, Zayed J, Labrèche F (2015) Effect of summer outdoor temperatures on work-related injuries in Quebec (Canada). Occup Environ Med 72, 338-45. [Medline] [CrossRef]

24) Jay O, Kenny GP (2010) Heat exposure in the Canadian workplace. Am J Ind Med 53, 842-53. [Medline]

25) Donoghue AM (2004) Heat illness in the U.S. mining industry. Am J Ind Med 45, 351-6. [Medline] [CrossRef]

26) Donoghue AM, Sinclair MJ, Bates GP (2000) Heat exhaustion in a deep underground metalliferous mine. Occup Environ Med 57, 165-74. [Medline] [CrossRef]

27) Maeda T, Kaneko SY, Ohta M, Tanaka K, Sasaki A, Fukushima T (2006) Risk factors for heatstroke among Japanese forestry workers. J Occup Health 48, 223-9. 
[Medline] [CrossRef]

28) Petitti DB, Harlan SL, Chowell-Puente G, Ruddell D (2013) Occupation and environmental heat-associated deaths in Maricopa county, Arizona: a case-control study. PLoS One 8, e62596. [Medline] [CrossRef]

29) Morabito M, Iannuccilli M, Crisci A, Capecchi V, Baldasseroni A, Orlandini S, Gensini GF (2014) Air temperature exposure and outdoor occupational injuries: a significant cold effect in Central Italy. Occup Environ Med 71, 713-6. [Medline] [CrossRef]

30) Rameezdeen R, Elmualim A (2017) The impact of heat waves on occurrence and severity of construction accidents. Int J Environ Res Public Health 14, E70. [Medline] [CrossRef]

31) Jay O, Brotherhood JR (2016) Occupational heat stress in Australian workplaces. Temp Austin 3, 394-411. [Medline]

32) Yang Y, Chan APC (2017) Heat stress intervention research in construction: gaps and recommendations. Ind Health 55, 201-9. [Medline] [CrossRef]

33) Rowlinson S, Yunyanjia A, Li B, Chuanjingju C (2014) Management of climatic heat stress risk in construction: a review of practices, methodologies, and future research. Accid Anal Prev 66, 187-98. [Medline] [CrossRef]

34) Xiang J, Hansen A, Pisaniello D, Bi P (2015) Perceptions of workplace heat exposure and controls among occupational hygienists and relevant specialists in Australia. PLoS One 10, e0135040-12. [Medline] [CrossRef]

35) Xiang J, Hansen A, Pisaniello D, Bi P (2015) Extreme heat and occupational heat illnesses in South Australia, 20012010. Occup Environ Med 72, 580-6. [Medline] [CrossRef]

36) Xiang J, Bi P, Pisaniello D, Hansen A (2014) The impact of heatwaves on workers' health and safety in Adelaide, South Australia. Environ Res 133, 90-5. [Medline] [CrossRef]

37) Arndt V, Rothenbacher D, Daniel U, Zschenderlein B, Schuberth S, Brenner H (2005) Construction work and risk of occupational disability: a ten year follow up of 14,474 male workers. Occup Environ Med 62, 559-66. [Medline] [CrossRef]

38) Johnson KA, Ruppe J (2002) A job safety program for construction workers designed to reduce the potential for occupational injury using tool box training sessions and computer-assisted biofeedback stress management techniques. Int J Occup Saf Ergon 8, 321-9. [Medline] [CrossRef]

39) Boschman JS, van der Molen HF, Sluiter JK, Frings-Dresen MHW (2011) Occupational demands and health effects for bricklayers and construction supervisors: a systematic review. Am J Ind Med 54, 55-77. [Medline] [CrossRef]

40) Riccò M, Cattani S, Veronesi L, Colucci ME (2016) Knowledge, attitudes, beliefs and practices of construction workers towards tetanus vaccine in Northern Italy. Ind Health 54, 554-63. [Medline] [CrossRef]

41) Messeri A, Morabito M, Bonafede M, Bugani M, Levi M, Baldasseroni A, Binazzi A, Gozzini B, Orlandini S, Nybo L, Marinaccio A (2019) Heat stress perception among native and migrant workers in Italian industries - case studies from the construction and agricultural sectors. Int J Environ Res Public Health 16, E1090. [Medline] [CrossRef]

42) El-Shafei DA, Bolbol SA, Awad Allah MB, Abdelsalam AE (2018) Exertional heat illness: knowledge and behavior among construction workers. Environ Sci Pollut Res Int 25, 32269-76. [Medline] [CrossRef]

43) Riccò M (2018) Air temperature exposure and agricultural occupational injuries in the autonomous province of Trento (2000-2013, North-Eastern Italy). Int J Occup Med Environ Health 31, 317-31. [Medline]

44) Morabito M, Cecchi L, Crisci A, Modesti PA, Orlandini S (2006) Relationship between work-related accidents and hot weather conditions in Tuscany (central Italy). Ind Health 44, 458-64. [Medline] [CrossRef]

45) Otte im Kampe E, Kovats S, Hajat S (2016) Impact of high ambient temperature on unintentional injuries in highincome countries: a narrative systematic literature review. BMJ Open 6, e010399. [Medline] [CrossRef]

46) Tawatsupa B, Lim LLY, Kjellstrom T, Seubsman SA, Sleigh A, Thai Cohort Study Team (2012) Association between occupational heat stress and kidney disease among 37,816 workers in the Thai Cohort Study (TCS). J Epidemiol 22, 251-60. [Medline] [CrossRef]

47) Rocklöv J, Forsberg B, Ebi K, Bellander T (2014) Susceptibility to mortality related to temperature and heat and cold wave duration in the population of Stockholm County, Sweden. Glob Health Action 7, 22737. [Medline] [CrossRef]

48) Lian H, Ruan Y, Liang R, Liu X, Fan Z (2015) Shortterm effect of ambient temperature and the risk of stroke: a systematic review and meta-analysis. Int J Environ Res Public Health 12, 9068-88. [Medline] [CrossRef]

49) Yi W, Chan APC (2017) Effects of heat stress on construction labor productivity in Hong Kong: a case study of rebar workers. Int J Environ Res Public Health 14, E1055. [Medline] [CrossRef]

50) The Labour Agency of the Autonomous Province of Trento Local Job Creation: How Employment and Training Agencies can Help. https://www.oecd.org/cfe/leed/ localjobcreationreporttrento.htm. Accessed September 15, 2017.

51) Toreti A, Desiato F (2008) Changes in temperature extremes over Italy in the last 44 years. Int J Climatol 28, 733-45. [CrossRef]

52) Varghese BM, Hansen A, Nitschke M, Nairn J, HansonEasey S, Bi P, Pisaniello D (2019) Heatwave and workrelated injuries and illnesses in Adelaide, Australia: a casecrossover analysis using the Excess Heat Factor (EHF) as a universal heatwave index. Int Arch Occup Environ Health 92, 263-72. [Medline] [CrossRef]

53) Binazzi A, Levi M, Bonafede M, Bugani M, Messeri A, Morabito M, Marinaccio A, Baldasseroni A (2019) Evaluation of the impact of heat stress on the occurrence of occupational injuries: Meta-analysis of observational 
studies. Am J Ind Med 62, 233-43. [Medline] [CrossRef]

54) Lazzarotto W, Pasqualini O, Farina E, Bena A (2017) [Effectiveness of inspections in the construction sites on reducing innjuries: a pilot study in a Health Unit of Piedmont Region (Northern Italy)]. Epidemiol Prev 41, 109-15 (in Italian). [Medline]

55) Antoine M, Pierre-Edouard S, Jean-Luc B, David V (2007) Effective exposure to solar UV in building workers: influence of local and individual factors. J Expo Sci Environ Epidemiol 17, 58-68. [Medline] [CrossRef]
56) Zhang K, Arauz RF, Chen TH, Cooper SP (2016) Heat effects among migrant and seasonal farmworkers: a case study in Colorado. Occup Environ Med 73, 324-8. [Medline] [CrossRef]

57) Riccò M, Garbarino S, Bragazzi NL (2019) Migrant workers from the Eastern-Mediterranean region and occupational injuries: a retrospective database-based analysis from North-Eastern Italy. Int J Environ Res Public Health 16, 673. [Medline] [CrossRef] 